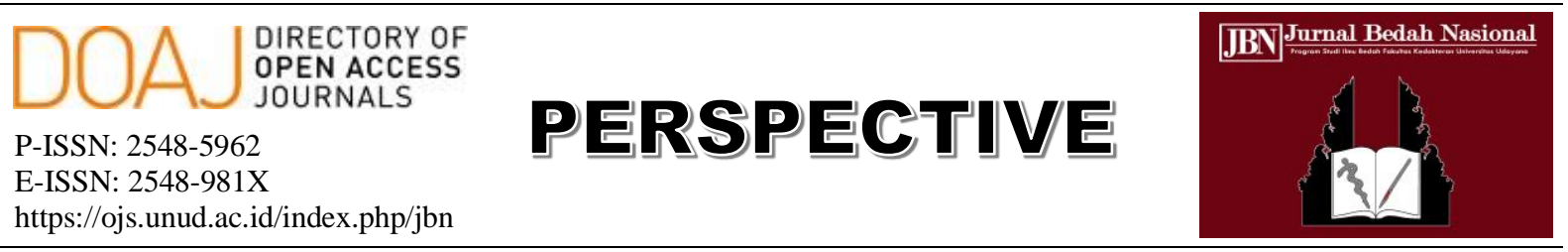

\title{
Pelayanan Terapi Radiasi Pada Pandemi COVID-19 di Instalasi Radioterapi RSUP Sanglah
}

\author{
Ngakan Putu Daksa Ganapati \\ Perhimpunan Dokter Spesialis Onkologi Radiasi Indonesia (PORI). \\ *Penulis korespondensi: putudaksa@gmail.com.
}

DOI: https://doi.org/10.24843/JBN.2020.v04.is01.p05

Pada akhir tahun 2019, dunia dikejutkan dengan adanya suatu wabah penyakit baru di daerah Wuhan, Cina. Tak berselang beberapa lama, wabah itu kemudian menyebar ke seluruh penjuru dunia. Pada tanggal 11 Maret 2020, badan kesehatan dunia (World Health Organisation / WHO) menyatakan wabah ini sebagai kondisi kasus pandemi ${ }^{1}$. Angka terakhir yang dilansir dari badan kesehatan dunia (WHO) menyebutkan 212 negara di dunia sudah terdampak, dengan sekitar 1.356.780 kasus positif dan 79.385 kematian telah tercatat akibat wabah ini. $^{2}$

Wabah tersebut disebabkan oleh varian baru dari virus influenza yang dikenal sebagai Virus Corona, dengan nama resmi untuk penyakit ini adalah COVID-19. Jenis varian virus ini relatif baru dan penyebarannya sangat cepat, dengan media penularan tersering adalah dari cairan tubuh pasien terutama droplet yang berasal dari saluran pernapasan penderita. Namun, beberapa praktisi kesehatan mulai mewaspadai pola penyebaran penyakit ini melalui medium udara (airbone).

Beberapa kelompok orang mempunyai risiko keparahan penyakit dan bahkan mortalitas yang lebih tinggi terhadap penyakit ini. Kelompok orang tersebut antara lain kelompok orang dengan usia tua, kelompok orang dengan penyakit seperti asma, diabetes, penyakit ginjal kronis, penyakit hati kronis, dan pada kelompok orang dengan imunitas menurun seperti pasien HIV, pasien yang sedang menjalani pengobatan kanker, atau sedang dalam pengobatan dengan steroid dosis tinggi ${ }^{3-5}$.

Proses penyebaran penyakit ini yang sangat cepat memerlukan perhatian khusus, terutama bagi tempat-tempat yang memungkinkan terjadinya perpindahan infeksi antar penderita atau ke masyarakat awam maupun tenaga medis. Salah satu tempat yang berisiko itu adalah Instalasi Radioterapi RSUP Sanglah yang hampir seluruh pasien yang ditangani adalah pasien kanker, dengan adanya indikasi penurunan kemampuan imun tubuh pada penderita kanker. $^{6}$

Selain dikarenakan oleh penyakit kanker yang diderita, faktor usia para pasien yang menjalani radioterapi menjadi pertimbangan, dikarenakan sekitar $40 \%$ pasien instalasi radioterapi RSUP Sanglah pada bulan MaretApril 2020 berusia $>60$ tahun. Disamping itu, adanya pendamping pasien yang dapat berbeda-beda setiap harinya dan juga domisili penderita yang relatif heterogen.

Dari sudut pandang tenaga medis yang melayani pasien, instalasi radioterapi memiliki keistimewaan tersendiri. Hal tersebut dikarenakan profesi-profesi yang bekerja di Instalasi Radioterapi RSUP Sanglah memiliki keterampilan yang tidak dimiliki oleh tenaga medis di bagian lain, terlebih lagi saat ini pelayanan radioterapi di 
Pulau Bali hanya tersedia di RSUP Sanglah. Profesi tersebut antara lain dokter spesialis Onkologi Radiasi, radiografer khusus radioterapi (Radiotherapy Technologist / RTT), fisikawan medis radioterapi, serta tenaga khusus ruang Mould Room.

Dalam hal peralatan, keterbatasan peralatan yang dimiliki (saat ini hanya 1 mesin teleterapi yang beroperasi) perlu menjadi perhatian. Satu mesin digunakan oleh semua pasien, sehingga mesin teleterapi dapat merupakan salah satu media transmisi dari virus sehingga dapat menjadi sumber penularan infeksi untuk pasien lain maupun tenaga kesehatan yang bertugas.

Pada saat ini pelayanan radioterapi tetap kami berikan, mengingat sebagian besar pasien yang kami layani adalah pasien yang sedang menjalani radiasi, dan proses penghentian secara mendadak mempunyai dampak yang tidak baik dalam hal kontrol lokal maupun angka kesintasan pada pasien. Faktor lain yang menjadi pertimbangan adalah adanya pembatasan penjadwalan operasi akibat pandemi ini, dikarenakan adanya risiko tinggi penularan selama prosedur medis pembedahan dilakukan maupun atas pertimbangan logistik dari alat pelindung diri maupun ketersediaan ruangan intensif paska pembedahan. Sayangnya sampai saat ini belum ada standarisasi jumlah pasien ideal yang tetap dapat dilayani dalam masa pandemi ini, dikarenakan bervariasinya kondisi untuk masing-masing pusat pelayanan radioterapi. Hal-hal tersebut patut menjadi pertimbangan dalam kelanjutan pelayanan radioterapi di masa pandemi COVID-19 seperti saat ini.

Untuk itu, Instalasi Radioterapi RSUP Sanglah menerapkan beberapa langkahlangkah dalam pelaksanaan pelayanan radiasi sehubungan dengan kondisi pandemi COVID-19.

\section{Langkah proteksi bagi petugas kesehatan di Instalasi Radioterapi.}

Petugas medis memiliki kerentanan yang lebih tinggi untuk terinfeksi dibandingkan jenis pekerjaan lainnya, terutama pada daerah dengan risiko tinggi. ${ }^{7}$ Petugas medis di Instalasi radioterapi mengikuti panduan penggunaan Alat Pelindung Diri (APD) di lingkungan medis, terutama yang berasal dari rekomendasi kementerian kesehatan $^{8}$ serta organisasi profesi, dalam hal ini Perhimpunan Dokter Spesialis Onkologi Radiasi Indonesia (PORI). ${ }^{9}$

Dalam rekomendasi tersebut, pemakaian level APD disesuaikan dengan pembagian area dalam Instalasi radioterapi serta dijelaskan juga mengenai standar proses desinfeksi pada peralatan setelah pemakaian untuk pasien.

Menyikapi himbaun untuk melakukan physical distancing, segala macam pertemuan di Instalasi Radioterapi telah ditiadakan. Jika diperlukan suatu rapat pembahasan pasien, kami menyarankan penggunaan aplikasi berbasis internet. Untuk selanjutnya kemungkinan akan diperlukan strategi rotasi tenaga untuk meyikapi jangka waktu pandemi yang belum dapat ditentukan lamanya.

\section{Langkah proteksi terhadap pasien di Instalasi Radioterapi.}

Terdapat penyesuaian terhadap alur pelayanan pasien di Instalasi Radioterapi, antara lain:

a. Untuk pasien yang sedang menjalani terapi Radiasi.

- Para pasien dan pengantar diwajibkan untuk menggunakan masker (masker kain bagi yang tidak mengalami gejala atau masker bedah bagi pasien yang mengalami gejala ringan gangguan pernapasan seperti batuk atau pilek). 
- Jumlah pengantar per pasien dibatasi maksimal 1 orang per pasien (kecuali pada pasien dengan keterbatasan berat, diperbolehkan sampai 2 orang).

- Edukasi untuk selalu mencuci tangan, serta penyediaan cairan hand sanitizer di beberapa tempat di Instalasi.

- Pelaksanaan terapi radiasi sesuai kluster yang telah ditentukan, dengan terlebih dahulu membuat penjadwalan terapi radiasi dengan waktu yang spesifik untuk masing-masing pasien, sehingga diharapkan tidak terjadi penumpukan pasien dan pengantar ketika menunggu giliran terapi radiasi (Tabel 1).

- Pemanfaatan aplikasi pesan instan (WhatsApp), dengan cara membuat grup dan menyebarkan segala informasi melalui grup tersebut, termasuk jadwal kluster untuk terapi radiasi.

Tabel 1. Daftar kluster waktu pemberian terapi radiasi di Instalasi Radioterapi RSUP Sanglah.

\begin{tabular}{cc}
\hline $\begin{array}{c}\text { Waktu Terapi } \\
\text { Radiasi }\end{array}$ & $\begin{array}{c}\text { No Rekam } \\
\text { Medik }\end{array}$ \\
\hline $07.30-08.30$ & Pasien 1 \\
& Pasien 2 \\
& Pasien 3 \\
\hline $08.30-09.30$ & Pasien 4 \\
& Pasien 5 \\
& Pasien 6 \\
\hline \multicolumn{2}{c}{ dan seterusnya } \\
\hline
\end{tabular}

b. Untuk pasien akan menjalani terapi Radiasi.

- Untuk pasien yang akan menjalani terapi radiasi, perlu dipertimbangkan beberapa hal antara lain manfaat dari terapi radiasi, efek apabila terjadi penundaan terapi dan yang terpenting akibat jika terpapar dengan infeksi COVID-19. Beberapa tempat pelayanan radioterapi telah mengeluarkan rekomendasi mengenai prioritas pemilihan pasien yang akan mendapat terapi radiasi pada masa pandemi ini. Pemilahan ini sebagian besar didasarkan dari jenis kanker yang diderita pasien, dan juga faktor risiko adanya penyakit lain (terutama penyakit sistemik) sebagai komorbid pada pasien tersebut. ${ }^{10}$

- PORI juga telah mengeluarkan rekomendasi alur indikasi radiasi pada masa pandemi COVID-19 serta jika diperlukan indikasi penundaan terapi radiasi yang masih dimungkinkan atau yang dapat tidak diberikan beserta alternatif terapi. ${ }^{9}$

- Penentuan prioritas penjadwalan pasien di Instalasi Radioterapi RSUP Sanglah dalam masa pandemi ditentukan oleh beberapa faktor (Tabel 2).

- Sebelum mulai dilakukan terapi radiasi, diperlukan penapisan risiko infeksi COVID-19 pada pasien tersebut yang akan di dokumentasikan pada rekam medis. Penapisan yang dilakukan antara lain:

- Anamnesis yang cermat dan mendalam dilakukan terutama terkait pada gejala-gejala yang sering muncul pada kasus infeksi COVID-19.

- Riwayat kontak dengan orang dengan risiko tinggi (OTG, ODP, PDP, dan kasus positif COVID19).

○ Daerah domisili pasien.

- Faktor komorbid lain (terutama riwayat penyakit gangguan pernapasan, gangguan jantung, 
diabetes, dan penggunaan steroid dalam jangka waktu lama).

- Semua hal tersebut menjadi pertimbangan dokter Spesialis Onkologi Radiasi untuk mengambil keputusan memberikan terapi.

c. Untuk pasien yang telah selesai menjalani terapi Radiasi.
- Pada pasien-pasien yang telah selesai menjalani terapi radiasi, perawatan paska radiasi dapat dilakukan di fasilitas kesehatan terdekat dengan domisili penderita. Apabila diperlukan, penderita masih dapat berkonsultasi dengan petugas / dokter yang merawat melalui aplikasi pesan sosial maupun sarana telepon.

Tabel 2. Faktor penentuan prioritas terapi Radiasi

\begin{tabular}{ll}
\hline \multicolumn{1}{c}{ Faktor dengan prioritas lebih } & \multicolumn{1}{c}{ Keterangan } \\
\hline Diagnosis / jenis keganasan. & Kanker dengan kondisi patologi \\
& anatomi yang bersifat radiosensitif, \\
& proliferasi cepat, serta pada kasus \\
& radiasi sebagai terapi kuratif utama \\
& (misal kanker leher rahim, kanker \\
& nasofaring) mendapat prioritas.
\end{tabular}

Adanya kondisi tertentu dalam Mendapat prioritas untuk segera onkologi (perdarahan aktif, sindrom dilakukan tindakan radiasi. vena kava superior, adanya keluhan akibat penyebaran tumor ke otak / tulang).

Adanya progresivitas pada penyakit Dipertimbangkan untuk dilakukan paska tata laksana definitf terapi radiasi, jika tidak ditemukan (kemoterapi / pembedahan) yang adanya faktor komorbid sistemik. menimbulkan gejala.

\begin{tabular}{ll}
\hline \multicolumn{1}{c}{ Faktor dengan prioritas kurang } & \multicolumn{1}{c}{ Keterangan } \\
\hline Kasus non keganasan. & $\begin{array}{l}\text { Untuk kasus non keganasan, dapat } \\
\text { dilakukan tindakan observasi terlebih. }\end{array}$
\end{tabular}

Kasus keganasan stadium awal paska terapi kanker definitif lain tanpa faktor risiko.

Pasien dengan Karnofsky Performance Score $(\mathrm{KPS})<70$, tanpa atau dengan disertai penyakit komorbid.
Radiasi dapat ditunda, dengan pilihan pengobatan medikamentosa (contoh : terapi hormonal).

Radiasi dapat ditunda, dengan mempertimbangkan risiko infeksi di rumah sakit. 
Radioterapi sebagai salah satu modalitas dalam tata laksana pasien kanker memiliki peran vital selama masa pandemi COVID-19 saat ini. Saat modalitas kanker lainnya terbatas untuk diberikan kepada pasien dengan alasan-alasan terkait pandemi, pelayanan radioterapi dapat tetap diberikan.

Namun, yang patut untuk dipertimbangkan adalah kondisi instalasi radioterapi yang sangat heterogen dengan alat yang relatif statis (satu alat digunakan oleh banyak pasien) serta kondisi pasien kanker yang sudah memiliki kerentanan terhadap infeksi COVID-19. Untuk itu diperlukan pengaturan alur pelayanan yang spesifik sesuai kondisi saat ini serta pembuatan skala prioritas dalam hal menentukan indikasi terapi radiasi.

Langkah-langkah yang telah diambil oleh Instalasi Radioterapi RSUP Sanglah saat ini mungkin masih jauh dari sempurna, namun hal tersebut masih dapat untuk diperbaiki sesuai dengan perkembangan kondisi peralatan dan sumber daya manusia serta dengan mempertimbangkan data-data dari pusat radioterapi di tempat lain.

\section{DAFTAR PUSTAKA}

1. World Health Organization. Coronavirus Disease (COVID-19) Pandemic. World Health Organization. [serial online] 2020 [diakses 9 April 2020]. Diunduh dari: https://www.who.int/emergencies/disease s/novel-coronavirus-2019.

2. World Health Organization. Coronavirus disease 2019 (COVID-19) Situation Report - 79. World Health Organization [serial online]. 8 April 2020 [diakses 9 April 2020]. Diunduh dari: https://www.who.int/docs/defaultsource/coronaviruse/situationreports/20200408-sitrep-79-covid19.pdf?sfvrsn=4796b143_4.
3. Verity R, Okell LC, Dorigatti I, dkk. Estimates of the severity of coronavirus disease 2019: a model-based analysis. Lancet Infect Dis. 2020.

4. Zhou F, Yu T, Du R, dkk. Clinical course and risk factors for mortality of adult inpatients with COVID-19 in Wuhan, China: a retrospective cohort study. Lancet. 2020;395:1054-62.

5. Centers for Disease Control and Prevention. Coronavirus Disease 2019 (COVID-19): People Who Are at Higher Risk - At Risk for Severe Illness. Centers for Disease Control and Prevention [serial online]. 2 April 2020 [diakses 9 April 2020]. Diunduh dari: https://www.cdc.gov/coronavirus/2019ncov/need-extra-precautions/groups-athigher-risk.html.

6. Chambers WH, Rabinowich $\mathrm{H}$, Herberman RB. Documentation of Immune Suppression in Cancer Patients. Dalam: Kufe DW, Pollock RE, Weichselbaum RR, dkk., editors. Holland-Frei Cancer Medicine. 6th edition. Hamilton (ON): BC Decker; 2003.

7. Ran L, Chen X, Wang Y, dkk. Risk Factors of Healthcare Workers with Corona Virus Disease 2019: A Retrospective Cohort Study in a Designated Hospital of Wuhan in China. Clin Infect Dis. 2020.

8. Kementerian Kesehatan Republik Indonesia. Petunjuk Teknik Alat Pelindung Diri (APD). Jakarta: Kementerian Kesehatan Republik Indonesia; 2020.

. Perhimpunan Dokter Spesialis Onkologi Radiasi Indonesia. Pedoman Pelayanan Onkologi Radiasi pada Pandemi COVID19. Jakarta: Perhimpunan Dokter Spesialis Onkologi Radiasi Indonesia; 2020. 
10. National Institute for Health and Care Excellence. COVID-19 rapid guideline: delivery of radiotherapy. London:
National Institute for Health and Care Excellence; 2020. 